\title{
Byblis guehoi (Byblidaceae), a new species from the Kimberley, Western Australia
}

\author{
Allen Lowrie ${ }^{1}$ and John G. Conran ${ }^{2}$
}

\author{
16 Glenn Place, Duncraig, Western Australia 6023 Australia \\ ${ }^{2}$ Australian Centre for Evolutionary Biology and Biodiversity Environmental Biology, DP 312 \\ School of Earth and Environmental Sciences, The University of Adelaide, SA 5005 Australia \\ Author for correspondence: john.conran@adelaide.edu.au
}

\begin{abstract}
A new species of carnivorous plant from the Kimberley region of Western Australia north east of Broome, Byblis guehoi Lowrie \& Conran, is described and illustrated. SEM micrographs of the seed, and chromosome data are also provided. The species is compact, multi-branched, glandular-leaved, bearing numerous flowers, and anchored to the soil by a solitary root system. When compared with other Byblis species, the new taxon is unique, differing in its particular combination of branching, floral, seed sculpturing characters, as well as being tetraploid.
\end{abstract}

\section{Introduction}

In August 2004, an unusual compact, much-branching, glandular carnivorous plant bearing many flowers and anchored to the soil by a solitary root system was discovered by Russ Guého north east of Broome in the Kimberley region of Western Australia (Fig. 1). When compared with known taxa in Lowrie and Conran's (1998) revision of Byblis in northern Australia, plus seed and chromosome features for the genus (Conran et al. 2002a, Conran et al. 2002b) the new taxon was clearly unlike any previously described species (Table 1) and is here described as new.

Byblis guehoi Lowrie \& Conran, sp. nov.

Affinis Byblide filifolia. Herba decumbens, ramulosa, e radice unica oriens. Pedicelli foliis longiores. Corolla subroseo-malvina, abaxialiter albida. Semina favosa cristis longitudinalibus denticulatis.

Holotype: WESTERN AUSTRALIA: 300 metres north of Bobbys Creek, near Beagle Bay Mission, c. 137 road km NE of Broome, Dampier Peninsula, Kimberley, 1657'39"S, 12246'26"E, A. Lowrie 3215 \& R. Guého, 6 September 2004 (PERTH). Isotype: MEL.

Paper from the Australian Systematic Botany Society Conference held in Cairns, November 2006 
Table 1. Comparison of Byblis geuhoi and related taxa. *refers to erect terminal shoots or branches; actual stems much longer but then decumbent or floating.

\begin{tabular}{|c|c|c|c|c|c|}
\hline Feature & B. guehoi & B. aquatica & B. filifolia & B. liniflora & B. rorida \\
\hline Habitat & wet/dry & wetlands & wetlands & wetlands & wet/dry \\
\hline Height $(\mathrm{cm})$ & up to $10^{*}$ & up to $5^{\star}$ & $20-60$ & $5-15$ & $6-30$ \\
\hline Branching & $\begin{array}{l}\text { multiple, } \\
\text { common }\end{array}$ & absent & few, rare & absent & few, rare \\
\hline $\begin{array}{l}\text { Sessile glands covering } \\
\text { shoot apex }\end{array}$ & absent & absent & absent & absent & present \\
\hline Pedicels longer than leaves & yes & no & no & yes & no \\
\hline Sepal length of petals & $>$ half & $<$ half & $>$ half & >half & $<$ half \\
\hline Petal colour abaxially & white & purple & $\begin{array}{l}\text { white to } \\
\text { yellow or } \\
\text { yellow and } \\
\text { mauve-striped }\end{array}$ & white & white \\
\hline Petal margins & dentate & rounded & $\begin{array}{l}\text { rounded } \\
\text { to denticulate }\end{array}$ & $\begin{array}{l}\text { rounded } \\
\text { to denticulate }\end{array}$ & dentate \\
\hline Filament colour & purple & pale lavender & pale lavender & pale lavender & purple \\
\hline Anther length of filaments & longer & $<$ half & longer & $<$ half & $<$ half \\
\hline Seed size (mm) & $\begin{array}{l}0.7-0.8 x \\
0.5-0.6\end{array}$ & $\begin{array}{l}0.9-1.3 x \\
0.4-.07\end{array}$ & $\begin{array}{l}0.4-1.1 x \\
0.3-0.8\end{array}$ & $\begin{array}{l}0.5-0.9 x \\
0.4-0.6\end{array}$ & $\begin{array}{l}0.5-0.8 x \\
0.4-0.6\end{array}$ \\
\hline Seed furrowing & absent & present & absent & absent & absent \\
\hline Seed anticlinal sculpturing & denticulate & smooth & $\begin{array}{l}\text { smooth to } \\
\text { denticulate }\end{array}$ & denticulate & denticulate \\
\hline Chromosome number (2n) & 32 & 16 & 16 & 32 & 16 \\
\hline
\end{tabular}

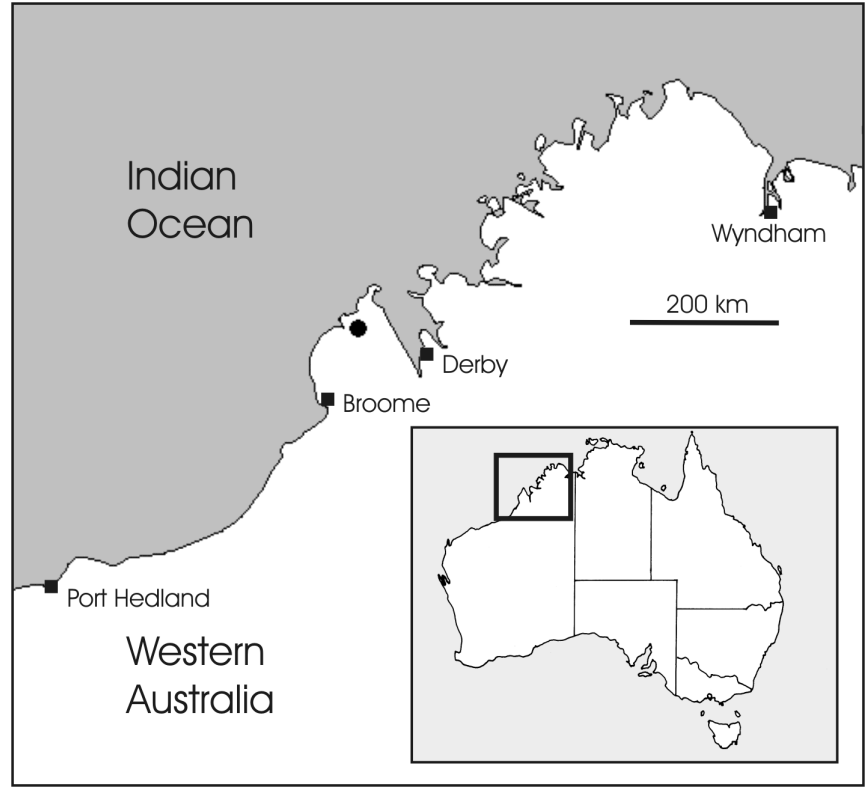

Fig. 1. Map showing the current single known locality for Byblis guehoi. 

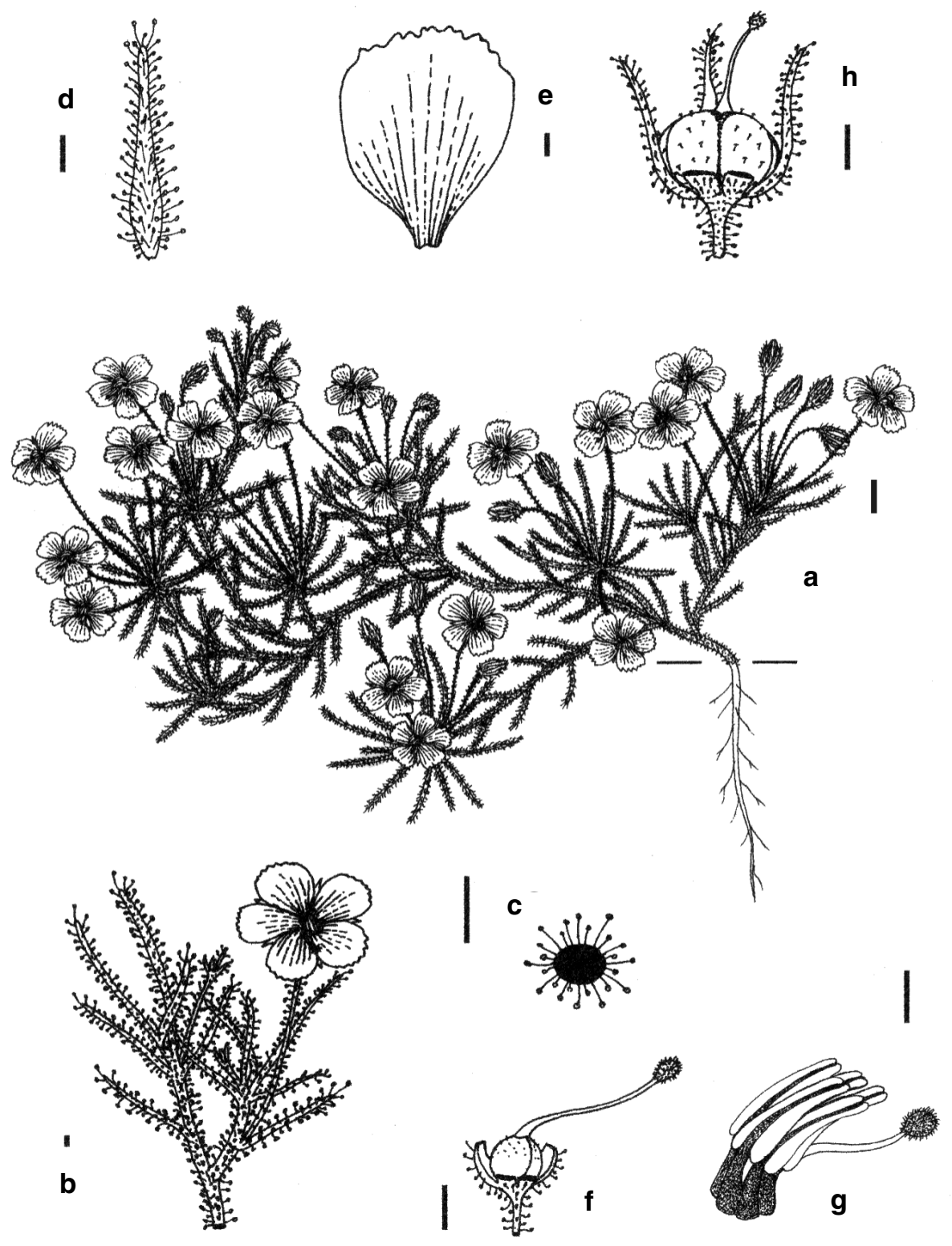

Fig. 2. Byblis guehoi a, plant; b, flowering shoot apex; c, leaf section; d, sepal; e, petal; f, ovary, filaments, anthers and style-stigma; $\mathbf{g}$, filaments-anthers, enlarged; $\mathbf{h}$, seed capsule. Scale bars for $\mathrm{a}=10 \mathrm{~mm}, \mathrm{~b}-\mathrm{h}=1 \mathrm{~mm}$. Drawn in 2006 by Allen Lowrie from live material collected from the type location; voucher A. Lowrie 3215 \& R. Guého (PERTH, MEL). 

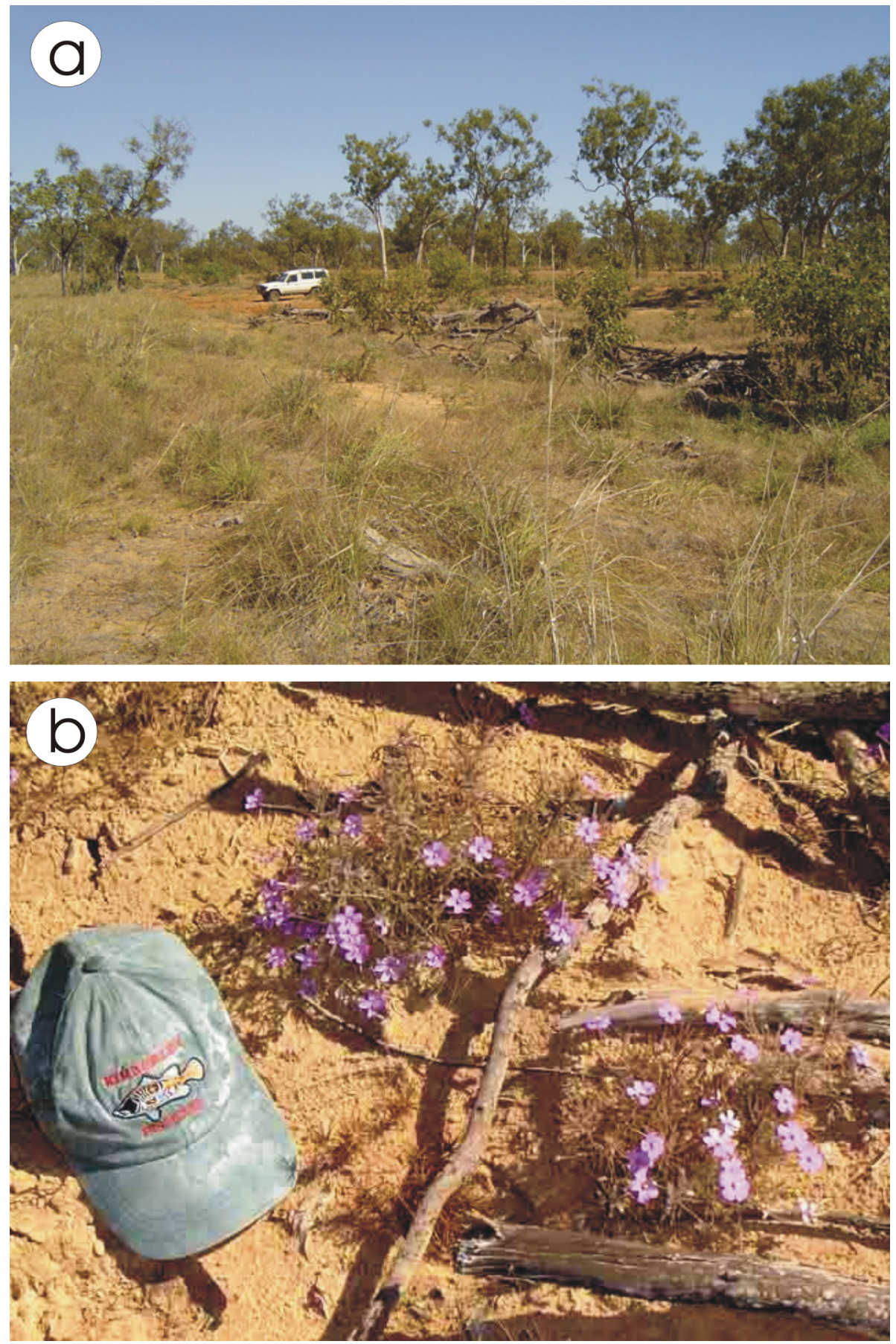

Fig. 3. Habitat at the type locality. a, Acacia-Eucalyptus open woodland with low tussock grasses and open sandy soil patches; b, Byblis guehoi growing on seasonally waterlogged but rapiddrying sandy loam. 

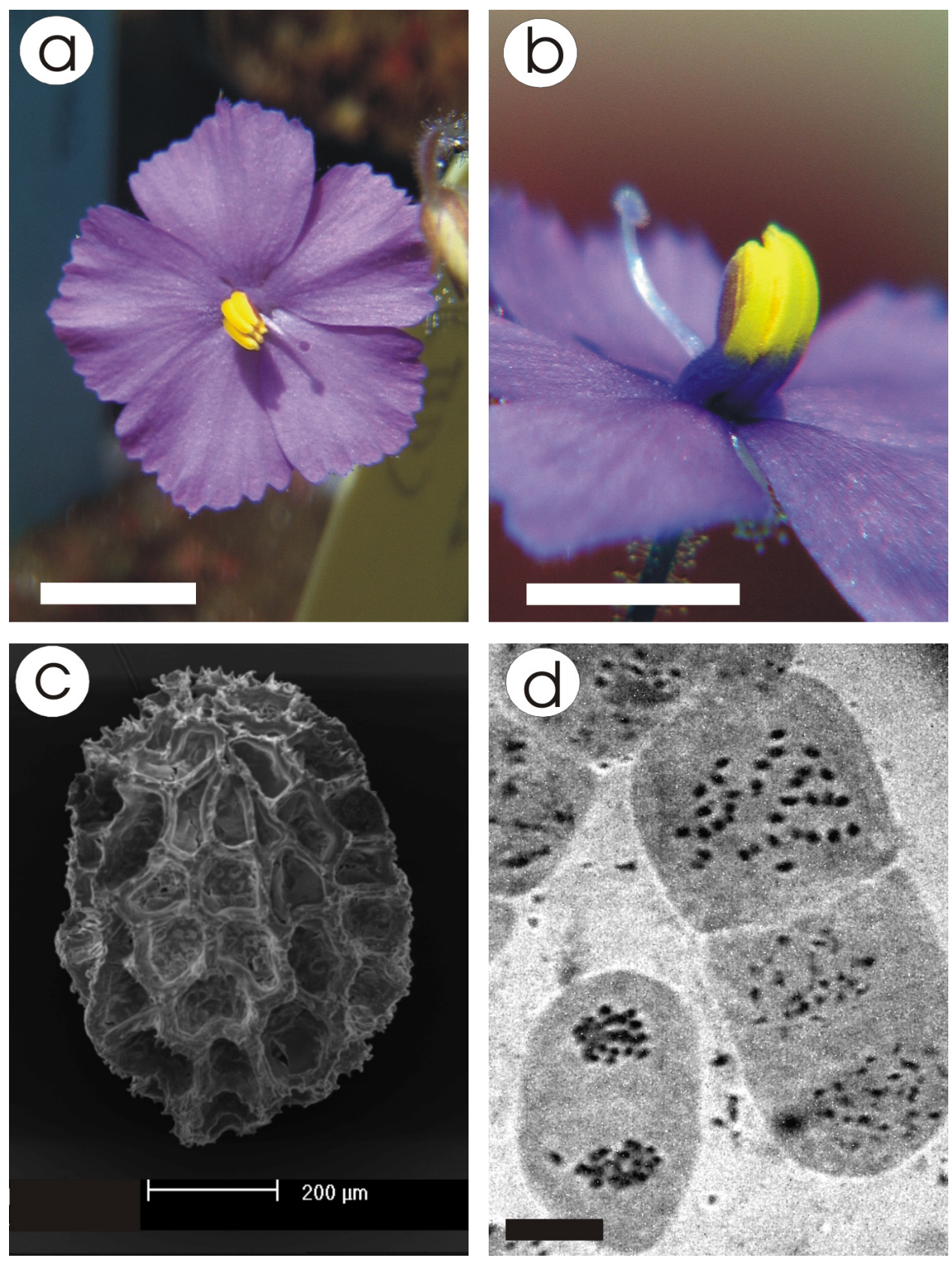

Fig. 4. Byblis guehoi $\mathbf{a}$, flower; $\mathbf{b}$, stamen detail showing deep colouring (purple) on the filaments and abaxially on the anthers; $\mathbf{c}$, seed; $\mathbf{d}$, chromosomes. Scale bar for $\mathrm{a}=10 \mathrm{~mm}, \mathrm{~b}=5 \mathrm{~mm}$, $\mathrm{c}$ as indicated, $\mathrm{d}=10 \mu \mathrm{m}$. Material grown at ADU from seed from the type locality; voucher A. Lowrie 3215 \& R. Guého (PERTH, MEL). 
Annual herb with one or more decumbent major axes 15-18 cm long, 2-3.5 mm diam., developing from a solitary root system, each terminating in an erect leafy many flowered head-like shoot, 6-8 cm tall, branching at random along their length and producing new major axis innovations terminating in a leafy flowering shoot; flowers under ideal moist growing conditions $15-20 \mathrm{~mm}$ diam., flowers produced as the dry season approaches much smaller, to one third this size; leafy apices of all leafy flowering shoots commonly producing a further compact 3 to 4 clusters of shorter stemmed leafy flowering shoots, together spreading to $20-30 \mathrm{~cm}$ diam.; overall colour appearing hazy (when viewed in full sunlight) because of the dense covering of translucent long and short glandular indumentum over the green- or bronze-coloured major axes, leaves and pedicels. Leaves filiform, shorter than the pedicels, $2.5-3.3 \mathrm{~cm}$ long, elliptic in section, c. $1 \mathrm{~mm}$ wide $\times$ c. $0.5 \mathrm{~mm}$ thick at the base tapering towards the apex; entire leaf length and circumference densely covered with long and short translucent glands. Inflorescences solitary, erect to semi-erect, arising from the axils of the leaves, pedicels longer than the leaves, $3.5-8 \mathrm{~cm}$ long, 1-1.5 mm diam. Sepals 5, green, lanceolate, apically \pm acute, outer surface glandular, $4.5-6 \mathrm{~mm}$ long, $0.8-1 \mathrm{~mm}$ wide near the base. Petals 5, adaxial flower surface pinkish mauve, (R.H.S. colour chart ${ }^{1}$, purple-violet $88 \mathrm{C}$ ) with faint darker mauve fan-like veining from the base, abaxial surfaces white, obovate, margins entire, except for the apex which is irregularly serrate and dentate, 9-12 mm long, 7-12 mm wide. Stamens 5, anthers longer than the supporting filaments, each longitudinally positioned close to each other, releasing pollen in unison, 4-6 mm long, filaments purple, clustered together, 1.5-2 mm long, anthers yellow with purple-brown longitudinal tapering supporting filament extension between, 3.5-4 mm long, pollen yellow. Ovary green, \pm globose, $1-1.5 \mathrm{~mm}$ diam. Style pale mauve, solitary, decurved to place the style below the anther cluster, longer than the stamens, $4.5-5 \mathrm{~mm}$ long, apically dilated, stigma darker mauve. Capsule broadly obovoid, compressed a little across its width, 3-4 mm long, 4-5 mm wide, sparsely glandular. Seeds black, shiny, irregularly shaped, \pm ovoid to elliptic in outline, $0.7-0.8 \mathrm{~mm}$ long, $0.5-0.6 \mathrm{~mm}$ diam., denticulate longitudinal ridges and shallow transverse ridges between, producing honeycomb-like sculpturing. (Figs 2-4).

Byblis guehoi (pronounced gay-ho-eye) is known currently only from the type location near Beagle Bay Mission, Kimberley, Western Australia (Fig. 1), but is locally abundant and not currently under threat. The vegetation consists of low native tussock grasses with open sandy soil patches between (Fig. 2a), bordered by scattered Acacia tumida F.Muell. ex Benth. (Mimosaceae) shrubs and trees, and taller Eucalyptus tetrodonta F.Muell., E. miniata A.Cunn. ex Schauer and Corymbia bella K.D.Hill \& L.A.S.Johnson (Myrtaceae) woodland on the higher ground. The species is found in open ground on an Orthic Tenosol soil consisting of a mixture of beige sand (a mix of amber colour tones and glass-like granules) and loam silt (Fig. 2b). These soils generally show low water retention capacity, are very nutrient-poor (Isbell et al. 1997), and, at the type locality, B. guehoi grows in a part of the Bobbys Creek watershed that is waterlogged in the wet season, but completely dry soon after.

\footnotetext{
${ }^{1}$ Royal Horticultural Society London. 1966. R.H.S. Colour Chart in association with the Flower Council of Holland. Published by The Royal Horticultural Society LONDON and Flower Council of Holland LEIDEN.
} 
Honours Russ Guého, the biologist, author, wildlife photographer and teacher from Broome who first collected the new taxon.

Byblis guehoi is easily distinguished from all other Byblis species by its decumbent, multibranching, head-like many-flowered habit. Its apically dentate petals are reminiscent of $B$. rorida, as is its more open, drier habitat, but it lacks the apical shoot glands and short sepals of that species (Fig. 3a). Anther length (Fig. 3b) places it with the B. filifolia complex but it differs in the seeds (Fig. 3c) and chromosome number (Fig. 3d). There are also features such as chromosome number and long pedicels which suggest affinities to $B$. liniflora, but phylogenetic relationships within the genus are currently unresolved and the subject of ongoing research.

\section{Acknowledgments}

Russ Guého is thanked for his significant help through his field collections and observations, data, personal comments and discussions since this species' discovery. DEC WA is thanked for permission to collect plant materials from lands under their control. Peter Wilson is thanked for assistance with the Latin diagnosis. The School of Earth and Environmental Sciences at The University of Adelaide is thanked for the provision of facilities to undertake part of the research.

\section{References}

Conran JG, Houben A \& Lowrie A (2002a) Chromosome numbers in Byblidaceae. Australian Journal of Botany 50: 583-586.

Conran JG, Lowrie A \& Moyle-Croft J (2002b) A revision of Byblis (Byblidaceae) in southwestern Australia. Nuytsia 15: 11-20.

Isbell RF, McDonald WS \& Ashton LJ (1997) Concepts and rationale of the Australian soil classification. (CSIRO Publishing: Melbourne).

Lowrie A \& Conran JG (1998) A taxonomic revision of the genus Byblis (Byblidaceae) in northern Australia. Nuytsia 12: 59-74.

Manuscript received 18 December 2006, accepted 27 August 2007 